\title{
Gail Edwards and Judith Saltman Picturing Canada: A History of Canadian Children's Illustrated Books and Publishing
}

Toronto: University of Toronto Press, 2010. vii, 381 pp.

\section{Catherine Carstairs}

University of Guelph

Picturing Canada traces the history of Canadian illustrated book publishing, focusing primarily on the 1970 s to the present. Impressively researched, it examines 573 children's illustrated books published in Canada between 1947 and 2005. For the period before 1950, Edwards and Saltman draw on literature with a strong Canadian focus as well as books written by Canadians. They supplement this with more than a hundred oral interviews with Canadian authors, illustrators, book designers, publishers and booksellers, as well as the papers of selected authors and illustrators. Interestingly, the book focuses more on the business, politics and culture of book publishing than on the writers. Thus, there is more attention paid to Patsy Aldana, the publisher of Groundwood Books, than there is to Robert Munsch, Canada's best-selling picture book author. This broad approach is perhaps especially useful for picture books, which are often a collaborative effort. As an historian, rather than a literary scholar, I was particularly impressed by the authors' attention to the material conditions of book publishing and to the culture and society of the period.

The book begins with a brief discussion of nineteenth and early-twentieth century children's literature including texts by Catharine Parr Trail, Ernest Thompson Seton and L.M. Montgomery. While the authors provide an able overview of the key developments in Canadian children's fiction, these sections fit uneasily with the rest of the text in that the remainder of the book focuses on picture books and not on the larger breadth of children's literature. After the Second World War, the authors explain, there was growing interest in telling Canadian stories and publishers expanded their Canadian lists, but the most knowledgeable analysts of children's literature in Canada believed that the overall quality of Canadian children's fiction was dismal. The first book to provide an overview of the field, Sheila Egoff's The 
Republic of Childhood (1967) condemned Canadian children's fiction as "distinctly second-rate" (65).

This would all change in the early 1970s with the emergence of numerous small presses and a renewed commitment to producing outstanding Canadian work. One of the pioneers was May Cutler who started Tundra Books in 1967 with the premise that picture books should be illustrated by artists, not graphic designers. Her output included Ann Blade's Mary of Mile 18, as well as William Kurelek's A Prairie Boy's Winter (1973) and a Prairie Boy's Summer (1975). Other small presses included: Books by Kids (which would later become Annick Press and move away from producing books written by children) and Kids Can Press. A number of regional and specialty presses also began producing books for children including: Canadian Women's Educational Press (later Women's Press), Breakwater Books and Douglas and McIntyre. Larger publishers, such as Oxford, McClelland and Stewart, and Macmillan, also developed their children's lists. In 1974 the Governor General's Award winning poet, Dennis Lee, published Alligator Pie, the first Canadian best-selling picture book. There was also more institutional support for children's literature: small provincial and federal grants supported small publishers; the National Library hired a children's librarian; newspapers began to expand their reviews of children's books; the first peer-reviewed journal of Canadian children's literature began at the University of Guelph; and the Canadian Society of Children's Authors, Illustrators and Performers was established in 1977. Not surprisingly, given the politics and nationalism of the era, this first generation of picture books had a strong emphasis on showcasing Canada's regional diversity, on promoting multiculturalism and tolerance, and on fighting sexism.

In the 1980s, children's publishing in Canada became more sophisticated and creative and achieved significant international success. Robert Munsch's feminist fairy tale, The Paper Bag Princess (1980), would sell more than a million copies while the Franklin series, published by Kids Can Press was translated into nine languages and eventually became a television series. The 1990s, by contrast, were significantly more challenging as specialty children's bookstores, like other independent bookstores, were forced out by the large chains. There was also less funding for school and public libraries and less government support for Canadian publishing. It became increasingly difficult for publishers to produce books with limited print runs; either a book was an immediate commercial success or it disappeared from the market very quickly. This has made it more difficult to produce unusual, or highly creative books, and has fostered the growth of books with strong commercial potential, especially if they can promote the sale of tie-in toys, DVDs and other items. The increasingly global nature of publishing has also forced Canadian publishers to be more conscious of American sensibilities and reduced their willingness to take risks.

A final chapter explores how Canadian identity is represented through picture books, with an emphasis on wilderness and multiculturalism and the telling of aboriginal stories. Before the 1970s, children's literature experts argued that aboriginal stories lacked the appropriate dramatic form and were too cruel and erotic for child audiences. In short, they needed to be re-interpreted by Euro-Canadians like James Houston and Kathleen Hill. By the 1980s, both aboriginal people and sympathetic 
scholars began to criticize these acts of cultural appropriation and aboriginal people began to write and illustrate their own stories, aided by aboriginal publishers such as Pemmican Press.

Picturing Canada should appeal to anyone interested in the history of book publishing, children's history and the history of nationalism and cultural politics in Canada. A few minor complaints: the book is amply illustrated but it is unfortunate that so many of the pictures are in black and white; the book lacks a strong overall argument which makes it better suited to academics in the field than for students; and the title should have indicated that this is primarily a history of English-language picture books. That said, it is a fascinating and insightful overview of the field and an important contribution to the literature. 